\title{
Social Work and Religious Diversity: Problems and Possibilities
}

\author{
PAUL F. KNITTER, ThD \\ Union Theological Seminary, New York, New York
}

\begin{abstract}
After exploring reasons why social workers need to engage in a kind of dialogue with their clients' religious beliefs and values, this article offers "virtues" that are required for such a dialogue. It then takes up problems that religious convictions can create both for the client and for the social worker. To deal with the problems, the article concludes with the resources that religion offers the social worker both for dealing with clients and for her or his personal life.

KEYWORDS religious diversity, dialogue, faith and belief, spirituality
\end{abstract}

In the following reflections, I'm really out of my element. The public I usually address, orally or in writing, is that of the academy of religious scholars or that of the churches, religious types whose worldview I basically share and whose language I understand. In what follows, I'm trying to address social workers, of whose work I have a general understanding (especially since I'm married to one) but whose professional language and methodology are rather foreign.

And yet, I am deeply convinced that the world of social work and the world of religions (especially in all of its diversity) are important for each other. For each to do its job, it has to know something about the other. That was part of the reason why the School of Social Work at Columbia University asked me to put together these reflections. I hope I have done so in a way that is both intelligible to social workers and respectful of the fact that they share many different views about the nature or the value or the danger

Received March 22, 2010; accepted April 7, 2010.

This is a lecture given at the invitation of the Columbia School of Social Work, March 3, 2010.

Address correspondence to Paul F. Knitter, ThD, Union Theological Seminary, 3041 Broadway at 121st St., New York, NY 10027. E-mail: pknitter@uts.columbia.edu 
of religion. I suspect that if we can get a conversation and collaboration going between schools of social work and schools of religion/theology there would be a lot to learn on both sides. In what follows, I'll be concentrating, as requested, on what social workers might gain from engaging religious diversity.

\section{SOCIAL WORKERS AND RELIGIOUS DIALOGUE}

The area of religious studies that has occupied me during the 46 years of my teaching career has been that of interreligious dialogue-how to get the religions of the world to stop hiding from or fighting with one another and recognize they have a lot to learn from one another and that the world in general would be better off if they did.

So it shouldn't come as a big surprise that the main claim of this essay is that social workers, in order to do their job in a culture in which religion is growing in intensity and diversity, have to engage in some form of religious dialogue. I begin my case first with some political, and then some psychological, considerations.

\section{The Religions Are Political Players Both Locally and Globally}

Today there is a broad recognition of the role that religion plays on the political stage, on both the local-political and the geopolitical stages. This has always been the case. But it has become forcefully and painfully clear in the events of 9/11 and, especially, after 9/11.

Both Osama bin Laden and George W. Bush appealed to religious values and motivations in response to the "evil" of imperialism or the "evil" of terrorism (Herbert, 2010). When you brand the other side as "evil," that means that God is on your side since God is always on the side of the "good-doers" in opposition to the "evildoers." On both sides of the geopolitical tensions, the two religions that are inspiring or guiding or justifying the political players, sometimes overtly something implicitly, are Islam and Christianity. The claim has even been made that after the years of cold war between capitalist and communist ideologies we now have a rather hot war between two civilizations that to a great extent are grounded in the messages of the Qu'ran and the Bible. This is the well known, and very controversial, claim of Samuel Huntington (1996): we are today facing a "clash of civilizations," which is really a clash of religions.

So on this issue of the presence and power of religion in the world of politics and international relations, I think we have to say that the Muslim theologians are right: religion and politics do mix, both actually and understandably. Yes, the United States holds to the principle of the separation of church and state and so forbids the government to side with religions 
in general in order to make sure it doesn't side with any one of them in particular. And many Muslims, especially those who are American or European citizens, would agree with this clear distinction between church and state, but they would add that this distinction doesn't necessarily lead to an actual separation. Muslims recognize and declare straightforwardly that religion and politics, unavoidably and perhaps necessarily, do mix. They hold up the fact that people who are truly convinced of their religious values will want those values to be translated into social values-yes, even into laws. Religious faith, when it is alive and well, cannot be only a personal, privatized affair; it will spill out from churches and from mosques into societies.

And crafty politicians will also know that if they want to advance their agendas among a people who publicly declare themselves to be religious, they'd better appeal to those religious convictions. Can you imagine the president of the United States ending a State of the Union address without an "and may God bless America"? The agenda of any president of this country, or any party, must be presented as having the blessing of God. Otherwise, there will not be enough votes to move it forward. That's a fact of life in the United States. (It certainly isn't in most European countries.)

So even the United Nations, which for most of its existence has shied away from any formal dealing with the political hornets nest of religion, has recently recognized that it can no longer avoid dealing with the diversity and the complexity of the religious world. In October 2007 I had the privilege of being part of hearings sponsored by the General Assembly on "Interreligious and Intercultural Understanding and Cooperation for Peace." The final report of these hearings opened with the following statement: "If religions are not part of the solution, they will continue to be part of the problem" (United Nations, 2007). The mess that religion has caused or contributed to is the kind of mess that only religion can solve.

Or, to put a much more positive spin on the UN's decision to take up the tangled matter of religion, the oft-quoted statement of Swiss theologian Hans Küng (1991) applies: "There will be no peace among nations without peace among religions. And there will be no peace among religions without greater dialogue between them" ( $\mathrm{p} . \mathrm{xv}$ ). Committed to the making of peace as is the UN, it must also be committed to the making of dialogue. The same, I suggest, applies to social workers.

\section{Social Work Requires Working with Religion}

If politicians, political scientists, and diplomats are recognizing that their jobs require them to deal with religion and religious faith, I believe that social workers must come to the same conclusion. For social workers, however, this necessity is rooted not so much in the geopolitical implications of the religions as in their psychological power. Religious faith affects, often 
determines, how people and communities feel about themselves, view their world, and act in their world. Our identities are determined by many factors. For religious people and religious cultures, religion is one of the primary factors.

This is so because of the intimate link between "behavior" and "beliefs." The ways we have been taught or socialized to behave, or the ways we choose to behave, give rise to and are sustained by our beliefs. Yes, as we so often hear, "It's more important to walk the talk than just talk the talk." But behind every "walk," there is a "talk." Behind our decisions to act in certain ways there is always, explicitly or implicitly, a set of values or beliefs that sustain and motivate such actions. I'm not saying that these beliefs are always religious. Not at all. They can be humanistic beliefs that call us to serve society, or they can be hedonistic beliefs that call us to serve ourselves. But if what we trust will truly make for our happiness is based on religious beliefs, then they are rooted in, and fortified by, a Reality that is more than human. Western cultures call this Reality "God." And if your identity is rooted in God, it can be very set in its ways.

If social workers, then, have to deal with religions, their job is going to be rendered all the more complex because today there are so many of them. Our Western societies, in Europe but especially in the United States and Canada, are fast becoming, or they have become, multireligious societies. If over the past century we have come to understand and speak of the United States as a uniquely multiracial and multiethnic society, it is now also a multireligious society. This means that if citizens of the United States recognize the equal rights of all races based on the equal value of all races, now they are being challenged to recognize the equal rights based on the equal value of multiple religions.

What I'm talking about is captured in the title of Diana Eck's (2001) book: A New Religious America: How a "Christian Country" Has Become the World's Most Religiously Diverse Nation. Religiously speaking, America is not the same country it was 200 years ago-really, not the same country it was 60 years ago. Eck describes how especially because of the more open immigration policies that were instated in the mid 1960s, and also because of the basic freedom of religion that we all enjoy in this country, America's religious garden, long a Christian monoculture (with some Jewish sprouts on the side), has become a multiculture of new religious forms and colors. As Eck points out, some of the new plants are outgrowing the old:

We are surprised to find that there are more Muslim Americans than Episcopalians, more Muslims than members of the Presbyterian Church USA, and as many Muslims as there are Jews-that is, about six million. We are astonished to learn that Los Angeles is the most complex Buddhist city in the world. . . Nationwide, the whole spectrum of Buddhists may number about four million. (Eck, 2001, pp. 2-3) 
Working with the Religions Calls for Dialogue

Working with your clients' religions is going to require more than what you've been trained to do when responding to their values and beliefs. It is going to require more than just respecting your clients' religion. You are also going to have to engage their beliefs, values, convictions. And this will call you to understand their religious beliefs not just as propositional statements but as personal commitments; you'll have to enter into these commitments and appreciate their power and their coherence. Engaging these beliefs will often lead you to try to either make positive use of them or to help your client see what you think are their harmful effects.

This can get dicey, I know. But I suspect that something like this is necessary if you're dealing with a client who is religious and takes his or her religion seriously. In some way, to some degree-different in each situation and for each client-you have to engage his or her religious values and beliefs.

All of this means that as social workers you have to know how to carry on what in my trade is called "religious dialogue." I'm upping the ante here. So let me explain: "dialogue" as understood by theologians can be described as follows: an interaction between two or more parties in which all participants recognize their own beliefs and values, describe those beliefs and values to one another, try to learn from one another, and are ready to change their minds in view of what they have learned, to the mutual benefit of all involved.

Something like this interaction of dialogue, I suggest, is what social workers must take up with all of their clients, especially with those who are religious. Of course, if the social worker is a religious person, he or she will not, in general, explicitly try to explain his or her own religious beliefs and values to the client. But, willy-nilly, whether the social worker realizes it or not, his or her own convictions about what makes for human and social well-being-whether those convictions are influenced by religion or notare going to enter into the relationship with the client. I believe that it is better to be conscious and honest about this.

\section{The Prerequisites or Virtues of Dialogue}

If what I'm saying makes any sense, an appropriate question would be: Well, then, how does one go about religious dialogue? What are the guidelines or "rules" for engaging in an effective dialogue? A recent book tries to answer these questions. Let me offer a sketchy summary of the five virtues that Professor Catherine Cornille of Boston College believes must be recognized and practiced if a conversation is going to move from chitchat to real dialogical engagement (Cornille, 2008). 


\section{HumiLiTy}

No dialogue or serious conversation has any hope of bearing fruit unless all of the participants bring to it the basic humility that recognizes that they all have something to learn. Whatever their personal beliefs and convictions may be, these beliefs must leave room for at least the possibility, if not the need, to broaden, clarify, even correct those convictions.

The need for such humility should be utterly compelling in religious conversations, for religion deals with that which is greater than and can never be fully comprehended by any human mind or system. To recognize God is to recognize one's own limitations.

\section{COMMITMENT}

In order to have something to talk about, participants in a dialogical relationship have to have their own commitments, their own "I hold these truths." Ideally, fruitful conversations are between people who stand for something. In their dialogues, social workers may need to help their clients identify or affirm their own convictions and commitments. And the social worker, as I said earlier, will generally not want to speak of his or her own commitments, but he or she must be aware of them and be ready to talk about them when appropriate or necessary.

By the way, in religious dialogue, you will perhaps sense that there can be a real tension between the virtue of humility and the virtue of commitment. Many religious people are not very humble about what they think their religions tells them is true.

\section{TRUST IN OUR COMMON HUMANITY}

This is the virtue that is really based on an act of faith, or trust, the trust that no matter how different we may be, no matter how diverse our social conditioning, there is the possibility of understanding one another, perhaps helping one another and learning from one another. As human beings, we are incredibly and incorrigibly different in our backgrounds and beliefs. But as human beings we always can find something "in common" on the basis of which we can understand one another.

This flies in the face of hard-core postmodernists who tell us that our social and cultural conditionings are "incommensurable." I don't believe that. I can't believe that, because if it is true that our cultural or religious differences are incommensurable, then, when they clash or are in conflict, the only way to resolve the conflict will have to be "who is tougher?" Violence.

\section{EMPATHY}

To really understand and value someone who is thoroughly different from me, especially if it is someone who may come across to me as "strange" or 
"weird" or repulsive, I am going to have to engage him or her with more than my intellect or reason. I will have to "empathize," which means try to enter into, or pass over to, the way he or she sees the world and feels the world.

It's not easy to describe how empathy works. It requires an engagement with the other that calls on our imagination, on our feelings. It requires letting go of our own thought-world in order to let our selves be taken into the world of the other. Native Americans are getting at this in the oftquoted saying, "Don't judge anyone until you have walked a few miles in their moccasins." Or as a friend of mine put it: "There is no one whom you would not appreciate and even love if you but knew their story" (Sr. Joan Chittister, O.S.B., in a personal conversation).

\section{OpEnNESS TO CHANGE}

If the previous four virtues are prerequisites for entering into the process of dialogue, this one is a prerequisite for its product or payoff. If we do indeed learn something from the other-something new, something that goes beyond or corrects our own beliefs and attitudes-we have to be open to letting that new truth claim us. That means we have to be ready to change our minds, to change our behavior, in light of the new truth and insights we have gained in the dialogue. If we're not open to change, then dialogue will turn out to be only chitchat, not anything that can make a difference in our lives.

So, if what I'm saying and suggesting makes sense, and if you do try to engage the religious beliefs and values of your clients in a kind of "religious dialogue," then you are going to face some really sticky problems but also some very promising possibilities.

\section{PROBLEMS}

\section{Problems on the Part of the Social Worker}

INADEQUATE PREPARATION FOR "RELIGIOUS DIALOGUE" WITH CLIENTS

One of the more immediate difficulties you're going to encounter in trying to engage or dialogue with the religious perspectives of your clients is probably the fact that it's all so strange to you. The world of religion is not easy to understand, especially when there are so many of them. It is usually difficult, sometimes impossible, to figure out and appreciate what someone in your own religious community or church really believes when they get into details of their own concept of God, or the devil, or heaven and hell. But when your client refers to "karma" or her "chi" or the "Pure Land Heaven" or "Shariah" it can all come across as religious Greek! (Pardon to the Greek speakers.)

Here we are touching on an infrastructural problem. For most social workers, in their primary and secondary education, and I suspect in their 
training even at as prestigious a program as the Columbia University School of Social Work, they don't learn a lot about religion and religious diversity. Even if they went to a denominational private high school or college, I doubt if their Christian or Jewish or Muslim religious education classes taught them much about how other people are religious. They may have had a college course in comparative religions but not much more.

Even though I'm an outsider and cannot appreciate the curricular complexities of social work programs, I make bold to offer a suggestion: that every school of social work have at least one course with a title something like the title of this article: "Social Work and Religious Diversity." I suspect it would have to be team-taught by a professor of social work and a scholar of comparative religion. I know there are a lot of scholars and/or theologians eager to lend a helping hand.

\section{IF THE SOCIAL WORKER IS A RELIGIOUS BELIEVER HERSELF OR HIMSELF}

You might think that if the social worker is a religious believer herself, she has a greater advantage in engaging the religion of her clients. I'm not so sure, especially if she is a Christian. From my study and experience, I've found that Christians generally have problems practicing the previously mentioned virtues of humility, empathy, and openness to change. The reason, simply but disturbingly, is that for most of the history of the Christian churches they have told their members, and proclaimed to the world, that Christianity was the only true religion because Jesus was the only Savior. All other religions were either worthless or second rate.

Now these teachings and attitudes have started to change. Christians, mainly in the mainline churches, are waking up to the fact that a "holier than thou" attitude does not make for good relations with their Muslim or Hindu neighbors. In my Roman Catholic Church, the Second Vatican Council that took place in Rome between 1962 and 1965 (I was a theology student in Rome at the time) was revolutionary in its call for dialogue with other religions. Still, in all of these newer, more positive attitudes toward other religions, most churches still teach that Christianity has first place in God's lineup of religions and that therefore all the others are inferior to Christianity. So if the social worker is a Christian with such beliefs and the client is from another religion (or maybe another Christian church!), it will be hard for him or her to take seriously, or be ready to learn from, someone she believes is religiously inferior.

Naturally, it's not just Christian social workers who may have this problem. Most of the religions, in one way or another, either expressly teach, or take it for granted, that theirs is God's preferred religion (if they are monotheists) or that their religion has achieved the highest form of enlightenment (if they are nontheists). 
Now you might say that social workers-whether they are Christians, Jews, or Buddhists-are supposed to put aside their own perspectives and beliefs in dealing with their clients. All I can say is that if those beliefs are religious-that is, if the social work thinks they are not just her viewpoints but God's - that may be pretty hard to do.

\section{IF THE SOCIAL WORKER IS A SECULAR HUMANIST}

Now if the social worker is not a religious person at all but would affirm what might be called humanistic values - the values associated with secular humanism-such a social worker may have just as many, if not more, problems in engaging the religious attitudes of his or her client. I would imagine that a nonreligious humanist would find it mystifyingly difficult to understand and empathize with the client's world of religious attitudes and feelings. It's hard to grasp and appreciate something that is utterly foreign to you, that's foreign not just because you know so little about it but because what you do know, you may not like.

This brings us to a thornier problem on the part of the secular humanist social worker: I've met a number of secular humanists whose disgust for all things religious is more entrenched and virulent than the disgust that some Christians have for other religions. Atheists can be as dogmatic about their convictions as are believers. I give you the recent books by the socalled new (and vociferous) atheists: Christopher Hitchens (2007), Richard Dawkins (2006), and to some extent Sam Harris (2005). It's hard to learn from, or even engage, something you think is not only silly and a waste of time but is harmful and dangerous. Unfortunately, these new atheists are right: religion can be very harmful and dangerous, which brings us to the problems that religion can create.

\section{Problems on the Part of the Client}

Let me start with a question that stirs up immediate answers: when you look over the history of humankind, has religion done more harm to humanity than good? I suppose there's ample data for either a yes or a no. But especially when one lines up a list of the wars and violence that religion has either instigated or abetted, religion's record looks pretty murky. So let me honest: as a religious scholar, and as a religious believer, I can't deny that religion can be, and all too often has been, horribly, persistently, creatively harmful.

But as a scholar of religion, let me add a qualifier or clarifier: there is abundant evidence, I believe, that most of the aberrations of religionespecially in the form of religious violence-are brought about by religious leaders who, consciously or subconsciously, use religion to manipulate others for their own self-serving purposes. Religion is one of the most effective tools for gaining control-I mean absolute control-over others. I used 
to half-seriously tease my undergraduate students with the invitation that if they want to get rich quickly, and if they can speak well and know their Bible, they should consider the profession of pastor or preacher.

Still, in blaming those who exploit religion for purposes of wealth or power, I don't want to deny how individuals themselves can misuse religion either to run away from their problems or to justify their actions. Religion is a powerful tool for avoidance or rationalization. You can sweep a lot of problems and a lot of decisions under the carpet of "God's will." God sent me lung cancer (despite my two packs a day), or God wants me to take this new job (even though it will disrupt my family).

I suspect that one big reason why individuals can so easily be exploited by religious leaders or so easily use religion as a crutch when they have two good psychological feet has to do with where religion originates in our brain (or I prefer: where in our brain we experience God or Enlightenment). Religion, I believe, is usually born in the right side of our brain. As William James (1902/1985) showed quite extensively in his classic The Varieties of Religious Experience, it's rooted in the affective side of the human being; it's a matter of feeling, and of trusting one's feelings.

But as in all of our human activities so also in our religious practices, the two sides of our brain, the two sides of our personhood, call to each other and have to be integrated. Here, I suspect, we find the problem with the exploitability of religion. For many believers, their religious lives and decisions take place primarily or almost exclusively in their feelings, in their imaginations and emotions. They feel a lot but don't think much about what they feel. Their religion is mostly emotion and little reason. When religious experience is divorced from religious reflection, when people turn off their reasoning abilities as they are carried along by religious sentiment and fervor, the door is opened to exploitation, harm, abuse. The religious philosopher Paul Ricoeur (1967) recognized this need in his pregnant short sentence: "Symbols give rise to thought." Religion begins with narratives, stories, and symbols that offer meaning. We have to think about, ask questions about, this meaning.

So religion is born in what we feel. But it grows up in how we think about what we feel. When we don't do that, we are as innocent, and maybe as dumb, as lambs before the shearer.

All of this is a bit abstract. Let me offer a few examples of some of the categories of problems that you may have to deal with in clients or communities that hold to a deep religious faith and view of the world.

OUR TRUE HOME IS IN HEAVEN: SO DON'T WORRY ABOUT HIS EARTHLY HOME

The belief that we are ultimately destined for another world and that ultimately this world will be discarded and replaced by the heavenly world can lead people to not take this life seriously, either personally, or politically, or 
environmentally. Belief in heaven as the only place where things will "be right" can allow us to put up with a lot of "wrong" here. In fact, religious people often believe that the more one suffers in this life, the greater will be their reward in heaven.

GOD'S WILL, OR KARMA: FATALISM

A belief that everything is predetermined by an omnipotent Power-or in the case of karma, by what was done in a previous life-can easily lead people to "tolerate the intolerable," or not to ask further questions. The result is a fatalism that squelches or prohibits any kind of responsibility or initiative.

\section{HUMAN SINFULNESS: SELF-ESTEEM}

The Christian teaching that we are essentially and incorrigibly sinners can have detrimental consequences on one's sense of self-worth and basic goodness. "God loves me even though I'm a worthless sinner" still leaves you a worthless sinner. Along the same lines, belief in the devil as a personal power, or in evil spirits that are out to get us and can assume control over us, can have extremely complex effects on the social worker's efforts to help people deal with their addictions.

\section{ATTITUDES TOWARD GENDER AND SEXUALITY}

I can't and perhaps don't need to go into details on the way religion-and here I can speak from experience in my own Roman Catholic Church-can cause or support patriarchy and homophobia. It's one thing to believe that women are to be subordinate to men or that gays are abnormal. But when it's God (or the Pope) who tells you that (Paul VI, 1965)! It's hard for the social worker to argue with God. And yet, if a social worker is going to address the needs of a client who thinks God wants her to obey an abusive husband or a client who believes he is "dirty" because he is attracted to men, the social worker is indeed going to have to "argue with" the client's notion of God or her or his religious conditioning.

In other words, the only way that a social worker is going to be able to deal with these religious roadblocks to health is by engaging them. That means understanding them, knowing something about their roots in longstanding doctrines, empathizing with them, challenging them in a dialogical, compassionate manner. That's a tall, but necessary, order.

\section{POSSIBILITIES}

At this point, I may have led you to suspect that indeed we might be better off without religion, that religion causes more harm than it offers help. Well, 
even if it is indeed the case that religion is more a bane than a blessing, I do believe that you still have to deal with it. Why? Simply because religion is not going to go away. Back in the 1960s, we thought that God and religion were dead. Well look around, especially at this country. So I suggest that you will make much better use of your time and energy if, instead of following the example of the "new atheists" and trying to do away with religion, you role up your sleeves and deal with it.

But as a religious believer myself, one who also gets paid to study the effects of religion, I certainly want to say more, for I do believe, on the basis of my "faith" and of my study, that there are abundant positive possibilities and genuine resources that social workers can find in religion in order to carry on their work of healing and restoring. Indeed, I would even suggest that the kinds of possibilities and resources that social workers can find in religion can probably not be found elsewhere.

\section{Religious Resources for the Client}

\section{RELIGION AS A SOURCE OF SELF-WORTH}

Despite all of the preaching about human sinfulness and depravity, the existential core of a person's religious experience, in Christianity and I venture to say in all of the world's religious traditions, is a reliable and powerful source of affirmation of human value and dignity. It's hard to imagine other more powerful sources. Religious experience, whether it is described as the experience of a personal God or of an enlightened state, communicates to the individual a sense and assurance that they are "part of something larger." They are not alone; they are not an accident (either biological or cosmic). In the symbolism of the Abrahamic religions, all human beings are children of God. In the imagery of Asian religions, they are manifestations or expressions of Brahman or Buddha-nature. The individual self and the Divine Self or Energy are connected, related, identical.

Whatever the metaphysics or theology, the psychological effect on the individual is a sense of affirmation and acceptance. Paul Tillich, who taught at Union Theological Seminary and whose chair I hold, described the essence of religious experience as "Accepting Acceptance." Accept that you are accepted, even though you may not have the slightest idea of what or who accepts you. If you can do this-or if you can let it happen to you-you are in touch with or are touched by the God that Tillich called "the Ground of Being" (Tillich, 1950).

I would add for the consideration of atheists: these positive psychological effects of religious experience-that is, the sense of being accepted or affirmed or empowered-are real and operative even if there really is no such thing as God or Nirvana. So, I'm suggesting that if social workers can help their struggling, confused, depressed clients to plug into this content of 
their religious identities, both client and social worker will have a lot going for them.

\section{RELIGION AS A SOURCE OF STRENGTH TO OVERCOME HELPLESSNESS}

This sense of not being alone, of being connected with that which is more, means for the religious person that one is never stuck. No situation, no matter how horrible, is ever hopeless. The reason for this is as simple as it is mysterious: religious faith assures a person that there is a resource of strength and creativity that he or she can count on. If their own resources and strength are depleted, there's a reserve that is always available.

Allow me a philosophical reflection: I don't think that most of the religions have been very good at providing an intellectually satisfying answer to why evil exists (Buddhism may be an exception.) But all of them do offer a psychologically satisfying and empowering response to what to do with evil. For religious believers, evil never has to have the last word. You can always find a way of responding to evil—maybe not today, but tomorrow. If, as Forrest Gump assures us, "shit happens," you can always find a way of cleaning it up, or stepping around it, or finding a path where there is less of it. As someone has said, "Anyone who believes that good and evil have a 50-50 chance does not really believe in God."

Please note what I'm trying to say here. The core teachings of most religions do not say that in the face of problems or suffering, just sit back and God will take care of it. On the contrary, in one form or another, religions teach that whatever God does, or however Nirvana is felt, it will be through you. If you are never alone, neither does God act alone. In Christian terms, yes we are "saved" by grace. That means by a power that is more than what we are, yet this power is real only when it becomes part of what we are.

\section{RELIGION AS A SOURCE OF LIBERATION AND SOCIAL TRANSFORMATION}

But the potential power of religion is not just for individuals struggling with depression or failure. It is also for communities, for ethnicities, for sexual identities who are caught in oppression. As Christian liberation theology has made clear (Brown, 1978), and as my wife and I have seen in our work in El Salvador during the 1980s and 1990s (with what are called "communidades ecclesiales de basis," or "basic church communities" who reflected on the Gospel in the context of their economic and political oppression), and as my colleague at Union, James Cone (1997), has shown for African Americans, religion can be a powerful resource for social and political transformation.

So Karl Marx was right. To give the full citation of a much quoted passage from his critique of Hegel's philosophy of right: "Religious distress is at the same time the expression of real distress and the protest against real distress. Religion is the sigh of the oppressed creature, the heart of a 
heartless world . . . the spirit of a spiritless situation." But he was not entirely right in his next sentence: "It is the opium of the people" (Marx, 1884). Yes, it can be, and has been, escapist opium. But it can also be revolutionary dynamite. It can be, as Marx suspected, "the spirit" that works to deal with and overcome "a spiritless situation."

What Christians call liberation theology is gaining ground in religions throughout the world. I witnessed this while attending the "Parliament of the World's Religions" in Melbourne, Australia, in December 2009. It gathered some 7,000 ordinary believers and religious leaders from 200 different religious groups. Of the more than 600 seminars and workshops, I would say $85 \%$ of them dealt with the role of religion in combating poverty, human rights violations, political corruption, environmental degradation, and racial and gender injustice. Religions are waking up to, or reaffirming, the "this-worldly" meaning and power of their messages.

Social workers have always recognized that the health of individuals depends on the health of society and that if individuals are to be transformed, this will require also the transformation of society and culture. Here too, I believe, religion can be a powerful ally.

\section{Religious Resources for the Social Worker}

Finally, hesitantly and I hope respectfully, I offer a more personal observation on how I think religion, in all of its diversity, can be of help to anyone engaged in the hard labor of social work. I make this recommendation to all social workers whether they are religious or secular, believers or nonbelievers, theists or atheists: All the religions, in many different ways and for many different reasons, affirm the need to regularly take time out in order to reconnect, or recharge. They speak about the necessity of "withdrawing" from time to time in order to "find strength" or to "balance" or to "center" oneself.

Theistic religions make this reminder in terms of putting oneself in the presence of God or finding that presence within oneself. Nontheistic religions speak of the need to be aware of the energy or the interbeing of the universe. All of them recognize the need for solitude, for getting away, for some form of silence. They tell us that we need occasions when we can just sit down and shut up and so turn off the rational chatter in our heads and connect with reality in other noncognitive ways. Meditation, yoga, silent prayer, mindful walks, wordless music - these are different forms of quieting down in a way that energizes or refocuses or centers us.

We all need to step back, sit down, and shut up. I suspect that social work is the kind of job that especially calls for that.

So, I do believe that social workers, not always but often enough, have to engage in a religious dialogue with their clients. That's no easy task. But if they learn how to do so, they can bring great benefit to their clients and to themselves. 


\section{REFERENCES}

Brown, R. M. (1978). Theology in a new key: Responding to liberation themes. Philadelphia: Westminster Press.

Cone, J. (1997). Black theology and black power. Maryknoll, NY: Orbis Books.

Cornille, C. (2008) The im-possibility of interreligious dialogue. New York: Crossroad Publishing Company.

Dawkins, R. (2006) The God delusion. Boston: Houghton Mifflin Co.

Eck, D. (2001) A new religious America: How a "Christian country" has become the world's most religiously diverse nation. San Francisco: Harper.

Harris, S. (2005). End of faith: Religion, terror, and the future of reason. New York: W. W. Norton \& Co.

Herbert, T. W. (2010). Faith-based war: From 9/11 to catastrophic success in Iraq. New York: Equinox Publishing.

Hitchens, C. (2007). God is not great: How religion poisons everything. New York: Twelve.

Huntington, S. (1996) The clash of civilizations and the remaking of world order. New York: Simon and Schuster.

James, W. (1985). The varieties of religious experience. Cambridge: Harvard University Press. (Originally published in 1902.)

Küng, H. (1991). Global responsibility: In search of a new world etbic. New York: Crossroad.

Marx, K. (1884). Introduction to a contribution to the critique of Hegel's philosophy of right. Cambridge: Cambridge University Press, 1970. Ed. Joseph O'Malley. Translators Annette Jolin and Joseph O'Malley.

Paul VI. (1965). Nostra Aetate: Declaration on the relation of the church to nonChristian religions: Second Vatican Council. Available at: http://www.vatican. va/archive/hist_councils/ii_vatican_council/documents/vat-ii_decl_19651028_ nostra-aetate_en.html.

Ricoeur, P. (1967). Conclusion: The symbol gives rise to thought. In The symbolism of evil (347-357). Boston: Beacon.

Tillich, P. (1950). You are accepted. In The shaking of the foundations (pp. 153-163). New York: Charles Scribner's Sons.

United Nations. (2007). High level dialogue on interreligious and intercultural cooperation for peace, October 4-5. Retrieved from http://unclef.com/ga/ 62/plenary/peaceculturehld/bkg.shtml. 